\title{
Description of Sodium Intake among Patients in a Kidney Care Outpatient Clinic
}

\author{
P Courtice ${ }^{1}$, A Seah ${ }^{1}$, A Sihoe ${ }^{1}$, L Renouf ${ }^{2}$, Y McIntosh ${ }^{2}$, T Kafka ${ }^{1}$, J Koh ${ }^{2}$ \\ ${ }^{1}$ UBC Dietetics Program, British Columbia, ${ }^{2}$ Providence Health Care, British Columbia
}

Introduction: Reducing sodium intake is a key management strategy in delaying progression of chronic kidney disease (CKD). ${ }^{1,2}$ The average sodium consumption in Canada is $3400 \mathrm{mg} / \mathrm{d}$, far exceeding the upper tolerable intake level of $2300 \mathrm{mg} /$ day. ${ }^{1,3}$ In Canada, breads/cereals, milk/dairy products, soups and fast food products are found to be significant sources of dietary sodium. ${ }^{4}$ The St. Paul's Hospital Kidney Care Clinic (KCC) in Vancouver uses the validated Scored Sodium Questionnaire-Screening Form (SSQ-SF) to identify high and low sodium consumers. The sodium intake of the KCC population has not been previously investigated.

Objectives: To describe the sample's sodium intake using SSQ-SF scores, the consumption frequency of SSQ-SF food categories, and how consumption patterns may vary with age and sex.

About the SSQ-SF: This screening form was developed and validated for renal patients. ${ }^{2,5}$ The SSQ-SF collects patients' consumption frequencies of 13 categories of high sodium foods. Each category is weighted differently according to average sodium content. The lowest possible total SSQ-SF score is 0 , while the highest possible score is 149 . The score cut-point of 50 correlates with $2300 \mathrm{mg}$ of sodium/day (upper tolerable intake level). Patients who score 50 or more are classified as "high sodium consumers", while those who score less than 50 are classified as "low sodium consumers".

Methods: A retrospective chart review was performed for all SSQ-SFs completed between July and November 2017. Descriptive statistics for the sample and sodium intake were generated.

\section{Results and Discussion:}

- 76 SSQ-SFs were analyzed for this study

- Mean SSQ-SF score was $52.5 \pm 17$ and median SSQ-SF score was 50.5

- Majority of sample (53\%) are classified as high sodium consumers

- Males are more likely to be high sodium consumers, coinciding with Canadian population data 4 (see Table 2)

- Age groups 61-70 years and 71-83 years had higher mean scores (56.0 \pm 15 and $56.1 \pm 17.6)$, than those of age groups $29-40$ years (47.3 \pm 16.6$), 41-50$ years $(46.1 \pm 20.3)$, and $51-60$ years $(46.3 \pm 14.9)$

- Males are more likely to consume processed meat than females (67\% of males versus $26 \%$ of females reported having processed meat at least once a week)

\section{References:}

. Kisease: Improving Global Outcome. KDIGO 2012 clinical practice guideline for the evaluation and management of chronic kidney disease. Kidney Int Suppl. 2013;3(1):5-14.

2. Mason B, Ross L, Gill E, Healy H, Juffs P, Kark A. Development and validation of a dietary screening tool for high sodium consumption in australian renal patients. J Ren Nutr. 2014;24(2):123-34.

3. Arcand J, Abdulaziz K, Bennett C, L'abbe MR, Manuel DG. Developing a web-based dietary sodium screening tool for personalized assessment and feedback. Appl Physiol Nutr Metab. 2014;39(3):413-4.

. Tanase CM, Koski KG, Laffey PJ, Cooper MJ, Cockell KA. Canadians continue to consume too much sodium and not enough potassium. Can J Public Health. 2011;102(3):164-8.

. Ross L, Chong SH, Mason B, Healy H. Development and Evaluation of a Scored Sodium Questionnaire-Screening Form for Kidney Disease Patients. J Ren Nutr. 2016 May;26(3):159-67. sodium consumption, contrasting Canadian population data ${ }^{4}$

- Bread (26\%), salt added during cooking (23\%) and processed meat $(19 \%)$ were the greatest contributors to SSQ-SF scores among high sodium consumers

- Study sample was similar in age and sex to the original SSQ-SF study ${ }^{5}$

Table 1: Characteristics of Patient Sample

\begin{tabular}{|c|c|c|c|c|c|}
\hline Descriptive & & & & & \\
\hline Characteristics & $(n=76)$ & & Total $(n=76)$ & Male & Female \\
\hline Sex & & & & $(n=45)$ & $(n=31)$ \\
\hline $\begin{array}{l}\text { Male } \\
\text { Female }\end{array}$ & $\begin{array}{l}45(59 \%) \\
31(41 \%)\end{array}$ & $\begin{array}{l}\text { Mean } \\
\text { (SSQ-SF score) }\end{array}$ & $52.5 \pm 17.0$ & $55.3 \pm 17.3$ & $48.4 \pm 15.9$ \\
\hline Age Categories & & $\begin{array}{l}\text { Median } \\
\text { (SSO-SF score) }\end{array}$ & 50.5 & 56.0 & 49.0 \\
\hline $29-40$ years & $4(5 \%)$ & (SSQ-SF score) & & & \\
\hline $41-50$ years & $10(13 \%)$ & & & & \\
\hline $51-60$ years & $14(18 \%)$ & High sodium & $40(53 \%)$ & $26(58 \%)$ & $14(45 \%)$ \\
\hline $61-70$ years & $21(28 \%)$ & consumers & & & \\
\hline $71-83$ years & $27(36 \%)$ & $\begin{array}{l}\text { (\% in each category) } \\
\text { Low sodium }\end{array}$ & $36(47 \%)$ & $19(42 \%)$ & $17(55 \%)$ \\
\hline $\begin{array}{l}\text { Mean (years) } \\
\text { Median (years) }\end{array}$ & $\begin{array}{c}63 \pm 13 \\
67\end{array}$ & $\begin{array}{l}\text { consumers } \\
\text { (\% in each category) }\end{array}$ & & & \\
\hline
\end{tabular}

Table 3: Differences in Consumption Frequencies of Selected Food Categories between High and Low Sodium Consumers

\begin{tabular}{|c|c|c|c|}
\hline All types of bread & $\begin{array}{l}\text { Doesn't } \\
\text { usually eat } \\
\text { bread }\end{array}$ & 1-2 slices/day & 3+slices/day \\
\hline High sodium consumers ( $n=40)$ & $2(5 \%)$ & $27(68 \%)$ & $11(27 \%)$ \\
\hline Low sodium consumers ( $n=36$ ) & $8(22 \%)$ & $22(61 \%)$ & $6(16 \%)$ \\
\hline Processed meat & $\begin{array}{c}\text { Rarely or } \\
\text { never eaten }\end{array}$ & $1-3 x /$ week & $\begin{array}{l}\text { At least } \\
1 \mathrm{x} / \text { day }\end{array}$ \\
\hline High sodium consumers $(n=40)$ & $11(28 \%)$ & $26(65 \%)$ & $3(8 \%)$ \\
\hline Low sodium consumers ( $n=36$ ) & $27(75 \%)$ & $9(25 \%)$ & $0(0 \%)$ \\
\hline Canned or packaged soup & $\begin{array}{c}\text { Rarely or } \\
\text { never eaten }\end{array}$ & $1-3 x /$ week & $\begin{array}{l}\text { At least } \\
1 \mathrm{x} / \text { day }\end{array}$ \\
\hline High sodium consumers $(n=40)$ & $29(73 \%)$ & $10(25 \%)$ & $1(3 \%)$ \\
\hline Low sodium consumers ( $n=36$ ) & $31(86 \%)$ & $4(11 \%)$ & $1(3 \%)$ \\
\hline
\end{tabular}

Conclusion: High sodium intake is prevalent in this population, and varies with age and sex. Males and older patients showed the highest average sodium consumption. Description of this sample will help KCC dietitians improve and expand strategies for low sodium education.

Significance to the field of dietetics: To our knowledge, this is one of the first studies to describe sodium consumption of a Canadian CKD patient population. The SSQ-SF is a quick and useful tool that other KCCs may use to describe the sodium intake patterns of their patients.

\section{Disclosure: Nothing to disclose}

Contact information: Ladan Shahvarani (Dani) Renouf, St. Paul's Hospital KCC dietitian DRenouf@providencehealth.bc.ca 